Journal of the Scholarship of Teaching and Learning, Vol. 19, No. 1, February 2019, pp. 86-95.

doi: 10.14434/josotl.v19i1.26785

\title{
A Case Study on Experiential Learning in a First-Year General Education Course
}

\author{
Nicole Maki Weller \\ Indiana University Kokomo \\ Julie Saam \\ Indiana University Kokomo
}

\begin{abstract}
Experiential-learning provides opportunities for students that feature a variety of highimpact practices including first-year seminars, internships, community learning, collaborative projects, and capstone seminars. To offer these high-impact practices for students, faculty from across disciplines and majors must be willing to incorporate these opportunities within their courses and degrees. Indiana University Kokomo has offered two successful programs to support these bigh-impact practices. One program, the Kokomo Experience and You (KEY), supports faculty in the development and implementation of events and activities to support student learning. The other, the Student Success Academy Faculty Fellows Program, provided faculty members the opportunity to examine research and concepts so that they can betterpromote student success in their classrooms. Building on the success of these two programs, a third initiative, the Experiential Learning Academy (ELA), was launched in 2018, funded by a Reimagining the First Years mini-grant from AASCU.

Key Words: experiential learning, faculty fellows model, high impact practices, Re-imagining the First Year, case study
\end{abstract}

\section{The Re-imagining the First Year of College Initiative}

From 2016-2018, Indiana University Kokomo was one of 44-member institutions participating in the Re-Imagining the First Year of College (RFY) project, which was facilitated by the American Association of State Colleges and Universities (AASCU) and funded by the Bill \& Melinda Gates Foundation. The participating institutions represented colleges and universities serving low-income, first generation, students of color; a subset of the student population that has been historically underserved by higher education. Working together, the 44 institutions developed and implemented institutional transformations to enhance the first year of college and to create sustainable change for student success. The driving force behind the RFY project was to redesign the first year of college a critical year for student success with the highest rates of student attrition.

At Indiana University Kokomo (IUK) two institutional initiatives were implemented to meet the expectations of the RFY project. The first was a campus-wide experiential-learning program called the KEY ("Kokomo Experience and You"), which features a wide variety of high-impact practices, including first-year seminars, internships, community learning, collaborative projects, and capstone seminars, as well as other forms of active, transformative learning, such as retreats, domestic travel, and career development. Under the KEY, students complete at least one of these experiences each year (for a total of four experiences for those students who come in as freshmen for four-year programs). Through a wide variety of hands-on experiences, students learn to apply and integrate their knowledge and skills, collaborate with others, take initiative, and develop a mindset for success and service. Along the way, they make important connections with classmates, faculty, staff, administrators, and members of the larger community while developing the confidence to become their best selves. 
The second initiative was the 2017 Indiana University Kokomo (IUK) Student Success Academy Faculty Fellows Program which provided a small group of faculty members the opportunity to research and study concepts (i.e. transparent learning, "Decoding the Disciplines," etc.) so they could better promote student success in their classrooms. The IUK Student Success Academy emulated the faculty learning community model which was introduced out of Miami University in the early 2000s. Cox (2004) describes the faculty learning community as a "cross-disciplinary faculty and staff group...who engage in an active, collaborative, yearlong program with a curriculum about enhancing teaching and learning..." (p. 8). These communities of practice allow faculty members to investigate a teaching and learning topic through an interdisciplinary lens and eventually realize the connections and integration of disciplines in regard to teaching and learning. The faculty learning community model is routinely a program to allow faculty to work within an administration role for a limited period of time, so they can develop their expertise as teachers. The IUK Student Success Academy Faculty Fellows program was a yearlong program where eight faculty members came together once a month to learn about teaching and learning strategies focused on the first-year student. The group had a common book, attended workshops, met with guest speakers, and held monthly discussions. Each fellow was then required to report on what they had learned by providing a handson workshop for campus faculty members.

The success of the KEY program and the Student Success Academy Faculty Fellows program highlighted additional unmet needs of student-learning and faculty engagement. The first was a need to integrate high-impact, experiential learning activities into first-year, general education courses in particular, versus a broader implementation across any course, in any year. The second was a need to increase participation in these activities among nonresident faculty. In 2017, the IUK Center for Teaching and Learning (CTLA) was awarded an RFY mini-grant from AASCU to launch a third initiative called the Experiential Learning Academy (ELA) that would meet the expectations of the RFY while simultaneously addressing these two, unmet needs. The ELA was built on the concept of the faculty learning community model, but unlike previous models that focused on student success in general, the ELA focused on experiential learning in particular. Moreover, the ELA was especially interested in involving lecturers and adjunct faculty, many of whom teach courses enrolled by firstyear students, but who represent a faculty base that has historically not been as engaged in the culture of experiential learning on the IUK campus. The overarching goal of the ELA was to meet the expectations of the RFY by focusing on the development and implementation of high-impact experiential learning activities into first-year courses through a collaborative fellowship of resident and nonresident faculty.

\section{The Experiential Learning Academy}

\section{Teaching and Learning Styles}

The Experiential Learning Academy (ELA) was launched to address unmet student learning needs and faculty engagement with a specific focus on experiential learning. The goals of the ELA were to address these needs by 1) integrating high-impact experiential learning activities throughout the curriculum, and not just as a one-time event; 2) focusing specifically on first-year, general education courses that enroll many undeclared students who, without an identified major, may miss out on discipline specific KEY events and, as a result, may feel less connected to the campus; and 3) actively recruiting nonresident faculty who disproportionately represent instructors teaching a first-year, general education course and can be essential in creating the connection between the student and the campus, and improving overall retention rates.

Journal of the Scholarship of Teaching and Learning, Vol. 19, No. 1, February 2019. josotl.indiana.edu 
The theoretical foundation of the ELA was based on four teaching and learning styles with demonstrated and purposeful experiential learning activities that serve a diverse range of student learners (Caulfield and Woods, 2013; Kuh, 2008). These four teaching and learning styles were selected by the faculty participating in the ELA in an effort to create uniformity across each course, regardless of the high-impact, experiential learning activity implemented in each individual course and because they have evidence-based approaches to teaching first-year courses (Lindblom-Ylanne et al, 2006; Hativa and Birenbaum, 2000). The four teaching and learning styles that guided the development and implementation of the high-impact, experiential learning activities included:

First-Year Seminars and Experiences - the first-year seminar provides collaborative learning opportunities for students through frequent interactions with faculty that emphasize critical inquiry, writing, intellectual and competency skill development (Kuh, 2008).

Collaborative Assignments and Projects - the focus of this teaching and learning style is to enhance collaborative problem-solving skills and to increase active and empathetic listening skills. The collaborative focus of these goals increases a student's broader understanding of others from different backgrounds and life experiences (Kuh, 2008).

Diversity/Global Learning - teaching and learning activities developed with a focus on diversity and global learning emphasize student exploration of cultures and life experiences that are diverse from their own realities, ranging from local to global differences (Kuh, 2008).

Service Learning, Community-Based Learning - the focus of this teaching and learning style is to provide students an opportunity to apply what they are learning in their course work to a real-world setting via community outreach, service learning, or some other community-university collaboration. Overwhelmingly, the goal is to provide students a structured environment to give back to the community while reflecting on how their academic work is connected to their social citizenship (Kuh, 2008).

The first ELA meeting focused on identifying, defining, and discussing these four learning styles, with faculty developing an initial curricular plan to integrate one or more of these teaching and learning styles into their course. Throughout the semester, the ELA focused on each of these four teaching and learning styles individually through readings, guest speakers, workshops, and discussions.

\section{Faculty Recruitment}

The faculty coordinator for the ELA facilitated two faculty recruitment efforts. In the first, the faculty coordinator met with the Academic Deans overseeing disciplines that represent the largest offerings of general education courses. The purpose of this meeting was twofold: to introduce the Deans to this new initiative; and to solicit recommendations for nonresident faculty the Deans identified as someone who would benefit from participating in the ELA. There are many nonresident faculty teaching on the IUK campus, and the Academic Deans served as the best resource for recommending those faculty that would continue to teach for IUK, that were interested in improving their experiential learning pedagogy, and had shown an interest in enhancing student learning through the KEY and other experiential learning opportunities. The second recruitment effort was a campus-wide call-out to all resident and nonresident faculty to apply to the ELA. Resident and nonresident faculty were eligible for the ELA if they met the following criteria:

- They were scheduled to teach a first-year, general education course during the 2018 Spring semester

- They could commit to attending bimonthly meetings facilitated by the ELA faculty coordinator throughout the 2018 Spring semester

Journal of the Scholarship of Teaching and Learning, Vol. 19, No. 1, February 2019. josotl.indiana.edu 
- They would develop and implement at least one, high-impact, experiential learning activity into their first-year, general education course

- They would assess and share student learning outcomes based on the experiential learning activities they develop and implemented out of the ELA

Interested faculty members were asked to submit their 2-3 paged application responding to the following prompts:

- What interests you most about this opportunity?

- Share an idea on experiential learning for first-year, general education courses you would like to begin to implement or explore.

- Identify which general education course(s) you will work on during the Experiential Learning Academy.

- What experiences or expertise will you contribute to a faculty fellows program? (e.g. collaborative work with faculty, teaching presentations to faculty, previous experiential learning projects, etc.)

- What are some ways you want to impact the quality of your students' learning? What are some differences in learning that you would like to see as a result?

Nine faculty fellows were selected to participate in the ELA, representing disciplines from Criminal Justice, English (two faculty fellows), History, Philosophy, Psychology (two faculty fellows), and Sociology (two faculty fellows). These disciplines are all housed in the School of Humanities and Social Sciences which offers the most general education courses on the IUK campus. The nine ELA faculty fellows included two tenure-track assistant professors, one non-tenure-track clinical assistant professor, five lecturers, and one adjunct professor.

\section{The Faculty Fellows Model}

The ELA was modeled from the Student Success Academy Faculty Fellows program that brought faculty from multiple disciplines together to collaborate on improving their pedagogical approaches towards experiential learning. Unlike the year-long Student Success Academy Faculty Fellows program which included a faculty presentation after the program concluded, the implementation of the ELA was limited to one semester, per guidelines established in the RFY mini-grant.

To accommodate this condensed timeline, recruitment and acceptance into the ELA occurred in December 2017 and the first ELA meeting was scheduled for early January 2018. From January through May 2017, there were bimonthly meetings that included discussions and workshops on how to develop and refine teaching methods to enhance student learning through experiential learning, there were invited guest speakers, readings on experiential learning and student learning, and a peerreview of each ELA faculty members experiential learning activity. The focus of the peer-review was to provide feedback on assessing student learning outcomes for the experiential learning activities, to address sustainability of the project, and to identify which theoretical teaching and learning student the activity supported. The overarching purpose of these bimonthly meetings, workshops, discussions, and peer review was to ensure that the ELA was meeting the criteria outlines in the RFY mini-grant, and that ELA faculty fellows would develop a set of tools and skills needed to continue integrating 
high-impact, experiential learning activities for all their first-year, general education courses in particular, but all their courses in general.

\section{Course Profiles}

Faculty fellows had the option to develop or revise an existing high-impact, experiential learning activity to meet the expectations of the ELA. All the high-impact, experiential learning activities were scheduled to occur late in spring semester, allowing faculty fellows time to collaborate on, and revise their high-impact, experiential learning activities based on material and resources gained in the bimonthly ELA meetings. There were eleven courses taught by the nine faculty fellows in the ELA. One faculty fellow from English integrated two different high-impact, experiential learning activities in two different English courses. Another faculty fellow from Psychology used the same high-impact, experiential learning activities in two separate sections of an Introduction to Psychology course. In total, 328 students were enrolled in an ELA identified course during the spring semester 2018. Table 1 provides a summary of the course titles and student enrollments.

Table 1. ELA Courses and Student Enrollments

\begin{tabular}{ll}
\hline Course Title & Student Enrollments \\
\hline Introduction to American Criminal Justice & 35 \\
\hline Introduction to World Masterpieces & 09 \\
\hline Introduction to Drama & 12 \\
\hline Elementary Composition & 20 \\
\hline History of Western Civilization & 28 \\
\hline Introduction to Philosophy & 37 \\
\hline Introduction to Psychology (3 sections) & 121 \\
\hline Introduction to Sociology (2 sections) & 66 \\
\hline \multicolumn{2}{c}{ Total \# Enrolled Students 328 } \\
\hline
\end{tabular}

What follows are brief descriptions of the course-specific high-impact, experiential learning activities developed or revised, and implemented as part of the ELA.

Introduction to American Criminal Justice - Mock Trails: Students were asked to research a news story, movie, or novel that presented a socio-moral dilemma as well as provided enough information to stage a mock trial with a prosecution and defense team. In small teams, students worked to collect evidence for either their prosecution or defense arguments. Students who were not acting as legal counsel were the jurors. Only primary sources and evidence relevant to the time could be used in the trial.

Introduction to World Masterpieces - Analyzing Social Reactions to Murder. The purpose of this assignment was to help students relate the societal frenzy of Jack the Ripper to the creation of The Lodger by Marie Belloc Lowndes (2015). Through use of historical documents and modern perspectives, students determined what led to the murders, how and why the killer(s) chose the victims, and who they think Jack the Ripper might have been. Using those conclusions and a systematic, logical approach, students developed their own theories about whether modern technology could have been useful in solving the cases.

Introduction to Drama - Students Teaching a Community Play: The purpose of this assignment was to give students an opportunity to share their insights and to teach others about a play with the goal of encouraging others to read or view it. As part of a small group, students selected a one-act play that discussed a significant current issue; students chose Trifles (domestic violence), Am I Blue? (neglect 
and abuse), and The Wedding Story (relationship choices and miscommunication). In groups, students gave a teaching presentation of the play, with discussion focused on the play's issues pertinent to a campus-wide movement to increase awareness of sexual and physical abuse.

Elementary Composition - A Blog for Student Writers: The assignment was designed for students to construct a blog, from start to launch, minimal facilitation from the instructor. Key benchmarks for the assignment were established, but the instructor adjusted those based on the direction students took the blog.

History of Western Civilization - Reacting to the Past: Students in this class participated in a Reacting to the Past mini-games focusing on Greek and Hellenistic philosophy. The game takes the form of an in-class student debate about several major themes that were debated by historical philosophers during the decline of the Classical Period of Greek history. The week before the in-class debate each student was assigned the role of a historical philosopher and provided background information on their assigned philosopher, as well as readings composed by, or about him or her. Students were required to read secondary and primary sources before preparing a position paper from the perspective of their philosopher so they were prepared to debate with other student/philosopher roles in class.

Introduction to Philosophy - Communities of Inquiry: Students were introduced to five community of inquiry sessions at the end of each learning module where they were presented with a unique learning stimulus (i.e. a short children's book, music, poem, film clip, thought experiment, or short philosophical reading). Students were tasked with developing questions for the stimulus and then they gathered in a community of inquiry to answer the questions and complete a metacognition reflection of the original student questions. Throughout the semester, the instructor gradually transferred the role as facilitator to student leaders.

Introduction to Psychology - Taking Sides: Students were assigned a series of readings that present various controversial topics. In response to an overarching question, the readings provided a position in support of, and a position in opposition, to the question. There were two topics selected for the course - the instructor provided both topics. For the first topic on whether addiction is a brain disease, the instructor provided the questions for the students. For the second round, the instructor provided students a choice of topics from which two sections chose gun control and one section chose whether or not video games are harmful to minors. In addition to reading the assigned readings, students were expected to do additional research to support their position, complete pro/con worksheets, selfreflection statements, and participate in online and in-class discussions and debates.

Introduction to Psychology - Art and Mediation: Students in this class spent a semester researching the health benefits of meditation and art. Students organized two campus-wide meditation and art workshops where students could meet for an hour to do some art (e.g. color, paint, draw) and participate in student-led meditation.

Introduction to Sociology - Text to Life: This multifaceted assignment began with students reading the memoir I am Malala: The Girl Who Stood Up for Education and W as Shot by the Taliban (Yousafzai, 2013), writing a short essay summarizing and analyzing the account from a sociological perspective, then engaging in a student-led, active class discussion. Next, students learned about educational inequalities in the U.S., specifically related to access to early childhood education through additional readings and a community partnership with Kokomo's Very Early Childhood Education Center (VECEC). Students visited the VECEC and worked together to collect books for the center via collection boxes on campus and in local businesses. Finally, students completed the "Text to Life" assignment, which included a reflection piece that asked them to rate the learning activities and assess their own learning.

Introduction to Sociology - Group Deviance Project: Randomly assigned student groups worked to develop and implement a deviant act on campus or the community. Deviant acts could not be illegal, could not result in any property damage, or impose any physical or emotional harm to other persons.

Journal of the Scholarship of Teaching and Learning, Vol. 19, No. 1, February 2019. josotl.indiana.edu 
Examples included playing tag in the library or sitting at a restaurant table with strangers. Students recorded their deviant acts, presented this to the class, and wrote a group paper on the sociological relevance of their deviant acts.

These course profiles provide evidence of the effectiveness of the ELA to integrate highimpact, experiential learning activities into first-year, general education courses. Participating faculty fellows utilized information gleaned from the ELA discussions, workshops, trainings, and peer feedback to develop and implement these particular activities into their courses. Since a disproportionally high percentage of students enrolled in these courses are undeclared students, the ELA was successful in providing high-impact, experiential learning opportunities that were not linked to a specific major, increasing rates of student engagement among undeclared students. Finally, by including Academic Deans as part of the initial recruitment effort, the ELA was able to recruit a majority nonresident faculty to participate as faculty fellows $(77 \%$ faculty fellows were nonresident faculty). The Deans assisted in the identification of nonresident faculty that would benefit from participating in the ELA, but moreover, their support of both the ELA and the participating faculty established the significance of high-impact, experiential learning across the general education curriculum, as well as the recognition that all faculty should have an opportunity to enhance their pedagogical toolkit to develop these types of learning activities.

\section{ELA Outcomes}

The goal of the ELA was twofold: to integrate high-impact, experiential learning activities into firstyear, general education courses, and to increase nonresident faculty participation in this curricular development. The outcomes of these two goals can be observed across three broader areas including the implications for first-year, general education courses; the implications for experiential learning activities; and the implications for the professional development for nonresident faculty. In this section, we address the implications of the ELA for these three groups.

\section{First-Year, General Education Courses}

The KEY program has successfully established the significance of experiential learning as part of student learning. Through the KEY, departments receive support to develop and offer experiential learning opportunities for students that directly map to the students degree of study. These KEY events are essential in demonstrating the applicability and relevance of a particular major in real world settings. This is a strength and limitation of the KEY, because so many KEY events are offered for students as part of their major. The first implication of the ELA was recognizing that experiential learning needs to occur across all stage of a student's college experience, even before they declare their major. By offering these types of activities within first-year, general education courses, students who have yet to declare a major will have increased opportunities to engage in experiential learning. The long-term effects of offering experiential learning activities within first-year, general education courses may improve retention rates for students who are still searching for their major while they are working towards completing their general education requirements. Furthermore, since all students, including transfer students, will enroll in at least one general education course on campus, the ELA approach ensures that all students have an opportunity to participate in an experiential learning activity that is based on the course they are taking and not the major they have declared.

Journal of the Scholarship of Teaching and Learning, Vol. 19, No. 1, February 2019. josotl.indiana.edu 


\section{Experiential Learning Activities}

A second implication of the ELA was using a theoretical foundation to develop and implement highimpact, experiential learning activities that could be integrated throughout the semester within a firstyear, general education course. Faculty fellows in the ELA spent the semester identifying, defining, and analyzing high-impact practices using the four teaching and student learning styles addressed earlier. The purpose of this focus was to establish a theoretical foundation as the motivation for the experiential learning activities. While many of the experiential learning activities that are offered on our campus are linked to specific degree outcomes, developing these types of activities for a general education course required a different approach, one that could be replicated across any general education course and could serve a diverse student body.

\section{Nonresident Faculty}

The ELA was particularly interested in recruiting nonresident faculty fellows. Since the RFY minigrant required a focus on first-year, general education courses, including nonresident faculty, who disproportionally teach these courses, made logistical sense. The third implication of the ELA outcomes was having a majority representation of nonresident faculty participate on this initiative. Often times nonresident faculty are not considered for these types of initiatives; a consequence of their contractual employment terms (i.e. these are not faculty seeking tenure). However, these faculty represent the majority of instructors who are teaching, interacting, and mentoring first-year students as they decide about their major, or even decide about returning for a second year. While the campus provides unique training opportunities for all resident and nonresident faculty, the ELA was one of the first initiatives that over-recruited from nonresident faculty, to increase their participation in a campus-wide initiative. As a result, many of the nonresident faculty from the ELA have been included on subsequent grants to integrate experiential learning activities across general education courses.

\section{Conclusion}

Building on the foundations of the KEY program and the Student Success Academy Faculty Fellows model, the Experiential Learning Academy provided faculty teaching a first-year, general education course opportunities to learn evidence-based practices in teaching and learning that focused on experiential learning in particular, instead of student success in general.

One of the largest measures of success stemming from the ELA was observed among faculty efforts to scale-up high-impact, experiential learning activities at an institutional level. For example, at the conclusion of the ELA, faculty fellows established a long-term goal to continue developing and implementing high-impact/experiential learning activities across all their courses. To accomplish this goal, the ELA faculty fellows established clear pathways between student learning outcomes, general education outcomes, faculty professional goals, and departmental outcomes. Faculty fellows spent time evaluating how their coursework is both influenced by, and complementary of their departments.

For these reasons, one of most significant outcomes of the ELA was outlining an ideal, reciprocal relationship that promotes high-impact, experiential learning activities and outcomes meeting the needs of the students, the faculty, the department, and the University. The faculty fellows spent time brainstorming systematic approaches to improving the loop between these four levels that is sustainable, rewarding, and attractive to each of the four groups. From these discussions, the faculty coordinator received a small grant to support faculty interested in running a Reacting to the Past game during Spring semester 2019, following the same structure of the Faculty Fellows Model with a specific focus on implementing one particular high-impact, experiential learning activity.

Journal of the Scholarship of Teaching and Learning, Vol. 19, No. 1, February 2019. josotl.indiana.edu 
The ELA is an initiative that could be replicated across any campus that is committed towards integrating high-impact, experiential learning activities across first-year, general education courses. No matter the delivery of general education on any campus, utilizing theoretical foundations to develop and implement high-impact experiential learning activities serves the student, the faculty and the University. Furthermore, as the proportion of adjunct, lecturer, and non-tenure track resident faculty continue to rise across campuses, developing opportunities for these faculty to develop evidencebased, high-impact practices will improve overall student learning.

The culmination of the high-impact, experiential activities implemented with support from the ELA has left students with a greater understanding of the college experience, and enhanced confidence to accomplish their goals. If you provide students with meaningful purpose and the tools for exploration and discovery, they will exceed expectations, create something new and usually quite good, and find the people they want to be.

\section{Acknowledgements}

This project was possible due to a Reimagining the First Years (RFY) mini-grant from the American Association of State Colleges and Universities, to help RFY campuses incorporate High Impact Practices into their first-year curriculum. The authors would also like to thank the KEY Initiative and the Center for Teaching, Learning and Assessment at Indiana University Kokomo for their support.

\section{References}

Arghode, V., Wang, J., and Lathan, A. (2017). Exploring professors' engaging instructional practices: A collective case study. Journal of the Scholarship of Teaching and Learning, 17 (4), 126149. https://doi: 10.14434/josotl.v17i4.22099

Caulfield, J. and Woods, T. (2013). Experiential learning: Exploring its long-term impact on socially responsible behavior. Journal of the Scholarship of Teaching and Learning, $13(2), 31-48$.

Cox, M. D. (2004) Introduction to faculty learning communities. New Directions for Teaching and Learning, 97.

Fried, J. (2013). Engaged learning: Why feelings matter. About Campus, 18 (1), 2-8. https://doi.org/10.1002/abc.21105

Gibbs, G. and Coffey, M. (2004). The impact of training university teachers on their teaching skills, their approach to teaching and the approach to learning of their students. Active Learning in Higher Education, 5(1), 87-100.

Hativa, N., \& Birenbaum, M. (2000). Who prefers what? Disciplinary differences in students' preferred approaches to teaching and learning styles. Research in Higher Education, 41(2), https://209-236. doi.org/10.1023/A:1007095205308

Kuh, G. D. (2008). High-impact educational practices: What they are, who has access to them, and why they matter. Washington, DC: Association of American Colleges and Universities.

Journal of the Scholarship of Teaching and Learning, Vol. 19, No. 1, February 2019. josotl.indiana.edu 
Kuh, G. D. (2007). What student engagement data tell us about college readiness. Peer Review, 9(1), 4-8.

Lindblom-Ylanne, S., Trigwell, K., Nevgi, A., \& Ashwin, P. (2006). How approaches to teaching are affected by discipline and teaching context. Studies in Higher Education, 31(3), 285-298. https://doi.org/10.1080/03075070600680539

Lowndes, M.B. (2015). The lodger. Newcastle upon Tyne, NE6 2PA, UK: Cambridge Publishing.

Sorcinelli, M. D. (1994) Effective approaches to new faculty development. Journal of Counseling \& Development, 72.

Yousafzai, M. (2013). I am Malala: The girl who stood up for education and was shot by the Taliban. New York, NY: Little, Brown, \& Company. 